(c) 2017, THE AUTHORS. Published by FASS and Elsevier Inc. on behalf of the American Dairy Science Association ${ }^{\circledR}$.

This is an open access article under the CC BY-NC-ND license (http://creativecommons.org/licenses/by-nc-nd/3.0/).

\title{
Effects of feeding extruded linseed on production performance and milk fatty acid profile in dairy cows: A meta-analysis
}

\author{
T. Meignan, ${ }^{*} \dagger^{1}$ C. Lechartier, $\ddagger$ G. Chesneau, $\dagger$ and N. Bareille* \\ *BIOEPAR, INRA, Oniris, La Chantrerie, F-44307 Nantes, France \\ †Valorex, La Messayais, F-35210 Combourtillé, France \\ łUnité de Recherche sur les Systèmes d'Elevage, Univ Bretagne Loire, Ecole Supérieure d'Agricultures, 55 rue Rabelais, F-49007 Angers, \\ France
}

\section{ABSTRACT}

The objectives of this study were to quantify the effects on production performance and milk fatty acid (FA) profile of feeding dairy cows extruded linseed (EL), a feed rich in $\alpha$-linolenic acid, and to assess the variability of the responses related to the dose of EL and the basal diet composition. This meta-analysis was carried out using only data from trials including a control diet without fat supplementation. The dependent variables were defined by the mean differences between values from EL-supplemented groups and values from control groups. The data were processed by regression testing the dose effect, multivariable regression testing the effect of each potential interfering factor associated with the dose effect, and then stepwise regression with backward elimination procedure with all potential interfering factors retained in previous steps. This entire strategy was also applied to a restricted data set, including only trials conducted inside a practical range of fat feeding (only supplemented diets with $<60 \mathrm{~g}$ of fat $/ \mathrm{kg}$ of dry matter and supplemented with $<600 \mathrm{~g}$ of fat from EL). The whole data set consisted of 17 publications, representing 21 control diets and 29 ELsupplemented diets. The daily intake of fat from EL supplementation ranged from 87 to $1,194 \mathrm{~g} / \mathrm{cow}$ per day. The dry matter intake was numerically reduced in high-fat diets. Extruded linseed supplementation increased milk yield $(0.72 \mathrm{~kg} / \mathrm{d}$ in the restricted data set) and decreased milk protein content by a dilutive effect $(-0.58 \mathrm{~g} / \mathrm{kg}$ in the restricted data set). No effect of dose or diet was identified on dry matter intake, milk yield, or milk protein content. Milk fat content decreased when EL was supplemented to diets with high proportion of corn silage in the forage $(-2.8 \mathrm{~g} /$ $\mathrm{kg}$ between low and high corn silage-based diets in the restricted data set) but did not decrease when the diet

Received August 9, 2016.

Accepted February 11, 2017.

${ }^{1}$ Corresponding author: thomas.meignan@oniris-nantes.fr contained alfalfa hay. Milk trans-10 18:1 proportion increased when EL was supplemented to high corn silage-based diets. A shift in ruminal biohydrogenation pathways, from trans-11 18:1 to trans-10 18:1, probably occurred when supplementing EL with high corn silagebased diets related to a change in the activity or composition of the microbial equilibrium in the rumen. The sum of pairs 4:0 to 14:0 (FA synthesized de novo by the udder), palmitic acid, and the sum of saturated FA decreased linearly, whereas oleic acid, vaccenic acid, rumenic acid, $\alpha$-linolenic acid, and the sums of mono- and polyunsaturated FA increased linearly when the daily intake of fat from EL was increased. In experimental conditions, EL supplementation increased linearly proportions of potentially human health-beneficial FA in milk (i.e., oleic acid, vaccenic acid, rumenic acid, $\alpha$-linolenic acid, total polyunsaturated FA), but should be used cautiously in corn silage-based diets.

Key words: dairy cow, extruded linseed, milk yield, milk fatty acid, meta-analysis

\section{INTRODUCTION}

The onset of lactation leads to profound physiological changes marked by a negative energy balance. Increasing the energy content of the diet should help limit the length and severity of the negative energy balance status while maintaining milk yield in high-producing dairy cows. Indeed, feeding fat to dairy cows could increase energy density of diets without increasing high-starch concentrate intake and reducing fiber intake, which are both negatively related to rumen function (Palmquist and Jenkins, 1980). However, the effects of fat addition to the diet on milk yield (MY; Rabiee et al., 2012), DMI (Allen, 2000), and milk fat content (MFC; Palmquist et al., 1993) are heterogeneous. These effects seem dependent on the nature of the fat supplement and its processing, the amount of fat supplemented (Jenkins, 1997), and the nature of the forage in the diet (Onetti and Grummer, 2004). Palmquist and Jenkins (1980) stated that the total fat in the diet should not exceed 
6 to $8 \%$ of DM to avoid the negative effects of lipids on rumen function associated with a high-fat diet.

Increasing knowledge about the potential benefits of $\alpha$-linolenic acid (ALA; cis-9,cis-12,cis-15 18:3), long chain n-3 fatty acids (FA), and low n-6-to-n-3 ratio on human health (Simopoulos, 2008; Barceló-Coblijn and Murphy, 2009; Rajaram, 2014) has raised consumer demand for better nutritional quality of fat in dairy products. Considerable evidence exists that milk FA composition can be rapidly and widely modulated by adding oilseeds to the diets of dairy cows (Chilliard et al., 2007).

Linseed oil contains about $55 \%$ of ALA (Petit, 2010), the n-3 FA precursor of long chain n-3 FA. However, in ruminants, PUFA are largely biohydrogenated in the rumen before their absorption in the small intestine. Glasser et al. (2008c) estimated by meta-analysis that $87 \%$ of the ALA ingested was biohydrogenated in the rumen. Indeed, adding PUFA to the diet leads to the formation of many intermediates of biohydrogenation in the rumen, in interaction with the ruminal microorganisms ecosystem (Jenkins et al., 2008), including trans FA and precursors of CLA that may induce milk fat depression (Shingfield et al., 2010). The efficacy of ALA transfer into the duodenum thus depends on the degree to which ALA is protected against ruminal biohydrogenation.

The extrusion of oilseeds is a heat treatment that may protect UFA against ruminal biohydrogenation and the rumen environment against the adverse effects of UFA (Sterk et al., 2012). Indeed, Kennelly (1996) stated that heat treatment denatures the protein matrix surrounding the fat droplets, thus reducing the UFA availability for rumen microorganisms. However, the effects of extrusion on ruminal degradability of oilseeds are inconsistent in the literature (Dang Van et al., 2011; Troegeler-Meynadier et al., 2014). The analysis of the protective effect of extrusion on UFA obviously depends on the oilseed form taken for comparison (i.e., free oil, raw, technologically or chemically treated), and on the method of evaluation of UFA biohydrogenation (i.e., duodenal flows or milk FA profiles; Doreau et al., 2009). Another hypothesis on the mechanism of the potential protective effect of extrusion on UFA is that extrusion increases the rate of oil release in the rumen fluid, resulting in a higher bypass of PUFA from the rumen to the duodenum compared with whole and rolled seeds (Chilliard et al., 2009; Doreau et al., 2009). Indeed, Reddy et al. (1994) stated that extrusion ruptures fat micelles, thus increasing fat release and postruminal absorption compared with whole seeds (Sterk et al., 2010).

The use of extruded linseed (EL) in diet of dairy cows could both increase the energy density of the diet and improve the milk FA profile while limiting the putative negative effects of PUFA on the rumen function. Glasser et al. (2008a) summarized the effects of various oilseed supplements (i.e., various sources and forms), including linseed supplements on MFC and milk FA using a meta-analysis approach. However, they pooled several linseed forms to obtain a sufficient amount of data. Extruded linseed was associated with micronized, ground, and whole linseeds in the analysis (Glasser et al., 2008a). The evaluation of the specific effects of EL supplementation was therefore limited. The study of factors describing basal diet composition as potential modulating factors to responses was also limited due to the scant available data in their subdata sets (Glasser et al., 2008a). Since the publication of the meta-analysis by Glasser et al. (2008a), the effects of EL supplementation in lactating dairy cow diets have been tested under multiple experimental conditions (Chilliard et al., 2009; Ferlay et al., 2010, 2013; Hurtaud et al., 2010; Lerch et al., 2012; Neveu et al., 2013, 2014; Oeffner et al., 2013); however, MY and milk composition responses to EL seem inconsistent (Petit, 2010). We hypothesized that the dose of EL and the composition of the basal diet could explain this variability. The objectives of our study were to quantify, using a meta-analysis approach, the effects of feeding dairy cows with EL on milk yield and milk components, including FA profile, and to assess whether the size of the dose supplemented and the composition of the basal diet could influence responses.

\section{MATERIALS AND METHODS}

\section{Literature Search and Selection of Publications}

Our literature search was conducted in the Web Of Science, Google Scholar, and CABI databases using the key words "extruded linseed," "linseed," "dairy," "cow," and "cattle," as well as French terms in the database of peer-reviewed Rencontres Autour des Recherches sur les Ruminants conference proceedings. References cited in papers of interest were also included.

Inclusion criteria of studies defined a priori by authors were (1) study with lactating dairy cows, (2) control diet without fat supplementation, (3) treatment diet supplemented with EL only (i.e., no other form of linseed and no other lipid supplement), (4) absence of alfalfa protein concentrate in control and ELsupplemented diets because it is an alternative ALA source (Hurtaud et al., 2013); and (5) DMI measured. Furthermore, exclusion criteria were applied to obtain an adequate number of similar and sufficiently detailed milk FA profiles: (1) unknown measure methodology, and (2) inadequate quality of measure and inadequate FA profile (insufficient length of the capillary column 
to separate methyl esters, insufficient percent of FA detected, insufficient FA detected).

\section{Data Collection and Processing}

Production variables of interest extracted from published data were average DMI $(\mathrm{kg} / \mathrm{cow} / \mathrm{d}), \mathrm{MY}(\mathrm{kg} /$ cow $/ \mathrm{d})$, milk fat content $(\mathrm{g} / \mathrm{kg})$ and milk fat yield (MFY; g/cow per day), milk protein content (MPC; $\mathrm{g} / \mathrm{kg}$ ), and milk protein yield (MPY; g/cow per day). Afterward, 4\% FCM (INRA, 2010) and 4\% FCM:DMI ratios were calculated. The FA variables of interest were chosen to focus on reflecting the nutritional quality of milk for human health and both the rumen and cow metabolism according to the literature (Chilliard et al., 2007; Glasser et al., 2008a; Średnicka-Tober et al., 2016) and available data in our data set. Sum of pairs 4:0 to 14:0, palmitic acid (PA; 16:0), oleic acid (OA; cis-9 18:1), trans-10 18:1, vaccenic acid (VA; trans-11 18:1), rumenic acid (RA; cis-9,trans-11 CLA), linoleic acid (LA; cis-9,cis-12 18:2), ALA (cis-9,cis-12,cis-15 18:3), sum of SFA, MUFA, and PUFA were therefore considered as FA variables of interest to be extracted. Fatty acids were reported as grams per $100 \mathrm{~g}$ of total FA measured. Furthermore, PA:ALA and LA:ALA ratios were calculated.

Dependent variables then were calculated from these raw data. A dependent variable was defined as a response to EL supplementation. For instance, MFC response was calculated as

$$
\Delta \mathrm{MFC}=\mathrm{MFC}_{\mathrm{EL}}-\mathrm{MFC}_{\text {control }}
$$

where $\triangle \mathrm{MFC}=\mathrm{MFC}$ response to EL supplementation, $\mathrm{MFC}_{\mathrm{EL}}=$ average MFC from the EL-supplemented group, and $\mathrm{MFC}_{\text {control }}=$ average MFC from the control group.

The within-study differences approach enabled us to take into account a large part of the variability existing between experiments (Glasser et al., 2008a). A publication could contain more than 1 feeding trial (i.e., more than 1 control group) and each feeding trial could contain more than 1 EL-supplemented group (i.e., 1 control group related to several supplemented groups). Only 4 trials studied a dose-effect of EL supplementation. For example, Hurtaud et al. (2010) used 2 amounts of EL compared with 1 control; thus, 2 responses consequently were considered in the data set (i.e., 2 pairs of control and supplemented groups, 2 rows in the data set).

The explanatory variable used to study responses to the dose of EL (i.e., our first objective) was the daily intake of fat from EL supplementation per cow (FEL) to homogenize EL dose data. Various commercial prod- ucts containing different doses of EL with different fat content were used in trials found in the database. For the calculation of FEL, the EL content and EL fat content $(\%)$ of each product were needed. The EL content and overall fat content of each commercial product (\%) were extracted from papers, or authors were contacted if data were not presented (Pezzi et al., 2007; Oeffner et al., 2013; Livingstone et al., 2015). The EL fat content of each product then was calculated by using the overall fat content and the fat content of the other components of the commercial product with data from the INRA (2010) database. The EL fat content value from INRA (2010) was used only for one paper (Egger et al., 2007). Finally, daily intake of EL (grams per cow) was assessed through diet composition and total DMI. As the control group was not supplemented, the FEL within study variation was equal to the intake of fat from EL in the supplemented group.

Explanatory variables extracted to study the modulation of responses to EL supplementation by diet composition (i.e., our second objective) were proportion of concentrates (\%), diet chemical composition (CP, $\mathrm{NDF}, \mathrm{ADF}$, starch, fat), energy level $\left(\mathrm{NE}_{\mathrm{L}}\right.$ expressed per kilogram of DM and also per cow per day), and forage nature. The forage nature of the diet was encoded into several qualitative variables according to the data distribution in our data set. It was characterized by the nature of the main forage (i.e., forage with the highest proportion in total forage), the proportion of corn silage (CS) in forage, and the inclusion of alfalfa hay. The main forage was categorized as corn silage, grass silage, hay, or alfalfa hay; the proportion of CS in forage as low CS-based diet (0 to $51 \%$ of total forage) or high CS-based diet (75 to $100 \%$ of total forage); and alfalfa hay as absent or present. These variables were considered as potential dietary interfering factors. In nutritional trials, within-study differences of nutritive components between experimental groups were ineluctable despite efforts made by experimenters to conduct trials with isoenergetic or isonitrogenous diets. Indeed, fat supplementation, and particularly large amounts of fat, replacing some of concentrates (carbohydrates and protein source as the control diet was not supplemented with a lipid source) modified the chemical composition of the diet other than just the fat content. Differences in nutritive components ( $\Delta \mathrm{CP}, \Delta \mathrm{NDF}, \Delta \mathrm{ADF}, \Delta$ starch), energy level $\left(\Delta \mathrm{NE}_{\mathrm{L}}\right)$, and concentrates between control and supplemented diets could be possible confounding effects on the relationship between EL supplementation and dependent variables (Rabiee et al., 2012). Differences in nutritive components were therefore also studied as potential dietary interfering factors.

Additional experimental conditions were considered as potential interfering factors. Study design (Latin 
square or randomized block), duration of the experimental feeding period, total number of animals in the trial and within each experimental group, animal factors (such as breed, DIM at the beginning of the experiment and parity), and value of the variable of interest of the control group were extracted.

In summary, the variables retained to explain responses to EL supplementation were the dose of EL assimilated to FEL as the main explanatory variable, some interfering factors related to the diet (including within-study differences of nutritive components), and additional interfering factors related to experimental conditions. The statistical unit was a pair of 1 control and 1 EL-supplemented group.

\section{Strategy and Statistical Analysis}

In a first step, descriptive statistics including univariate analysis (mean, SD, ranges of values), correlations matrices, and graphical analyses were performed. These analyses enabled us to detect extreme data and to make assumptions about potential confounding factors. They also provided an illustration of the shape of possible relationships between responses to EL supplementation and explanatory variables.

In a second step, 1-sample $t$-test was performed to compare responses (i.e., dependent variables defined as the difference between mean values of a variable from the supplemented and control groups) with the value of zero to identify the main effects of EL supplementation without considering any potential interfering factors (i.e., explanatory variables).

In a third step, relationships between responses and FEL were evaluated using linear models. Nonlinear responses were tested by including FEL as both a linear and a quadratic term using the following model:

$$
\Delta \mathrm{Y}_{i}=\beta_{0}+\beta_{1} F E L_{i}+\beta_{2} F E L_{i}^{2}+\varepsilon_{i},
$$

where $\Delta \mathrm{Y}_{i}=\mathrm{Y}$ response to extruded linseed supplementation in the ith pair of control and supplemented group, $F E L_{i}=$ daily intake of fat from extruded linseed supplementation per cow in the $i$ th supplemented group, $\beta_{0}=$ intercept, $\beta_{1}$ and $\beta_{2}=$ regression coefficients, and $\varepsilon_{i}=$ residual error $\sim N\left(0, \sigma^{2}\right)$.

In a fourth step, multivariable regressions, including FEL and a potential interfering factor among dietary factors and experimental factors, were conducted. The FEL was included as both a linear and a quadratic term. The potential interfering factors were included one by one in distinct models as a linear term and, depending on the type of the variable (quantitative or categorical), as a quadratic term. At the end of this step, all variables with $P$-value $<0.10$ were retained.

When the potential interfering factor was quantitative

$$
\begin{aligned}
& \Delta \mathrm{Y}_{i}=\beta_{0}+\beta_{1} F E L_{i}+\beta_{2} F E L_{i}^{2}+\beta_{3} I N T R F_{i}+ \\
& \beta_{4} I N T R F_{i}^{2}+\beta_{5} F E L_{i} \times I N T R F_{i}+\varepsilon_{i},
\end{aligned}
$$

and when the potential interfering factor was categorical

$$
\begin{aligned}
& \Delta \mathrm{Y}_{i}=\beta_{0}+\beta_{1} F E L_{i}+\beta_{2} F E L_{i}^{2}+ \\
& \beta_{3} I N T R F_{i}+\beta_{5} F E L_{i} \times I N T R F_{i}+\varepsilon_{i},
\end{aligned}
$$

where $\Delta \mathrm{Y}_{i}=\mathrm{Y}$ response to extruded linseed supplementation in the $i$ th pair of control and supplemented group, $F E L_{i}=$ daily intake of fat from extruded linseed supplementation per cow in the $i$ th supplemented group, $I N T R F_{i}=$ potential interfering factor in the $i$ th pair of control and supplemented group, $\beta_{0}=$ intercept, $\beta_{1}, \beta_{2}, \beta_{3}, \beta_{4}$, and $\beta_{5}=$ regression coefficients, and $\varepsilon_{i}=$ residual error $\sim N\left(0, \sigma^{2}\right)$.

In a fifth and final step, a stepwise regression with backward elimination procedure was carried out with only these variables using the same statistical model scheme as in step 4, but with several potential interfering factors.

In all of the models, collinearity of significant variables was measured by the variance inflation factor to control the overparameterization of models. The linear term was forced to remain in the model if it was contained in any quadratic term or 2-way interaction. At each step of these analyses, any observation associated with a studentized residual $>3$ or $<-3$ was defined as an outlier and the model was rerun without this observation (Sauvant et al., 2008). This process continued until no outliers remained. Models were evaluated using adjusted coefficient of determination and root mean square error. Models were validated with both graphical and statistical analysis of residuals distribution. All analyses were performed with software R ( R Core Team, 2016).

This entire strategy (i.e., the 5 steps) was also applied on a data set including only trials conducted inside a practical range of fat feeding. To assess production responses to EL supplementation without lowering animal production due to large amounts of fat (Palmquist and Jenkins, 1980), only diets with a fat content of less than $60 \mathrm{~g}$ of fat $/ \mathrm{kg}$ of DM were selected. This selection excluded 9 response data from which the rumen may have undergone adverse effects from feeding greater amounts of UFA (Jenkins, 1997). Furthermore, only 
Table 1. References, experimental design, and main production variables used to assess the effects on lactational performances of extruded linseed supplementation to dairy cow diet

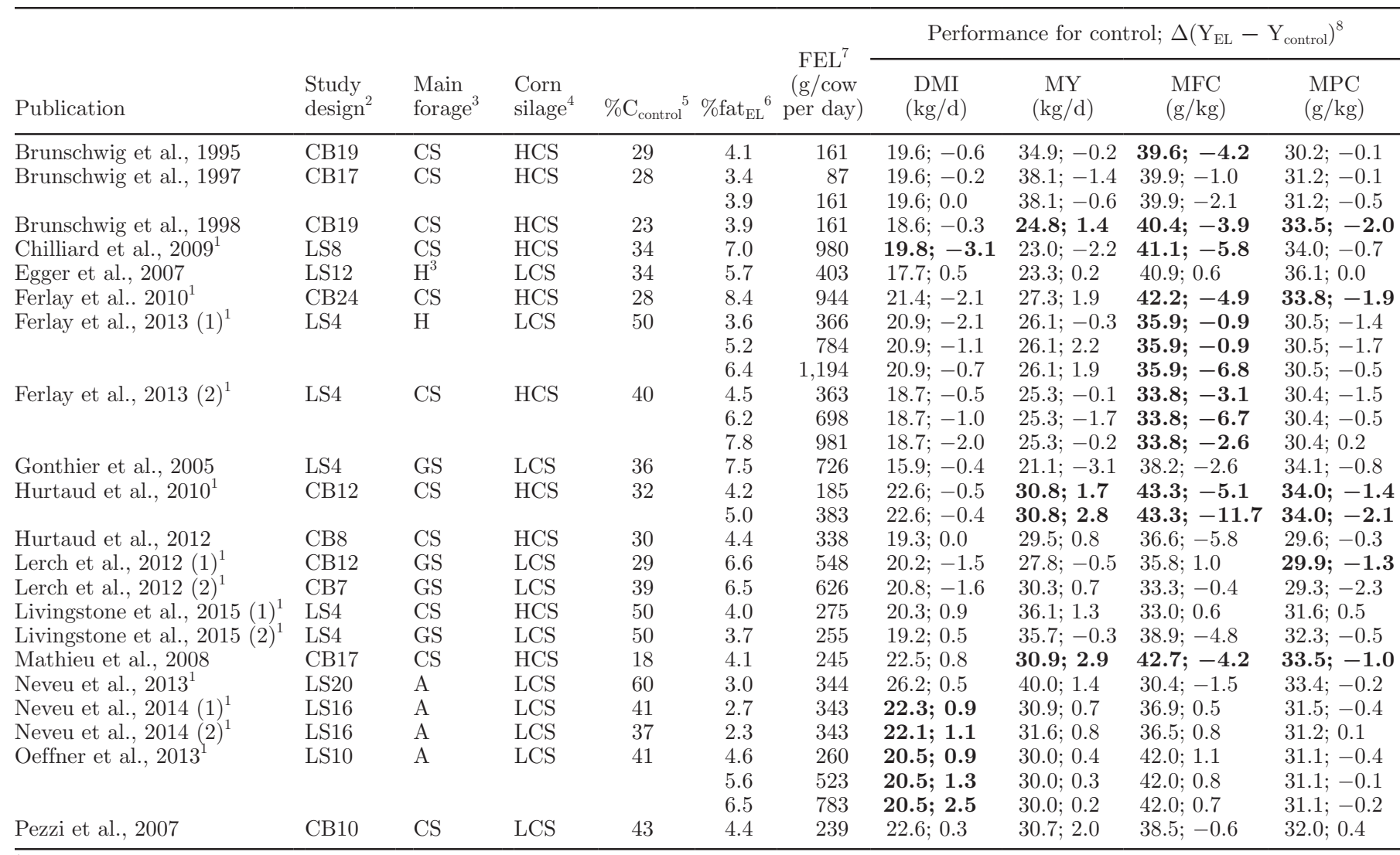

${ }^{1}$ Publications retained for fatty acids analysis. The number in parentheses indicates a different trial within a same publication (i.e., a different control group).

${ }^{2} \mathrm{CB}=$ continuous block, LS = Latin square. The number associated with the letters indicates the number of animals by block experimental group.

${ }^{3}$ Main forage of control diet: $\mathrm{CS}=$ corn silage, $\mathrm{H}=$ hay, $\mathrm{GS}=$ grass silage, $\mathrm{A}=$ alfalfa hay.

${ }^{4} \mathrm{LCS}=$ low corn silage-based diet (0 to $51 \%$ of total forage), HCS = high corn silage-based diet (75 to $100 \%$ of total forage).

${ }^{5} \% \mathrm{C}_{\text {control }}=$ proportion of concentrate in control diet $(\%)$.

${ }^{6} \% \mathrm{fat}_{\mathrm{EL}}=$ fat content of extruded linseed supplemented diet. The fat content of extruded linseed supplemented diets in Brunschwig et al. (1998), Hurtaud et al. (2012), and Mathieu et al. (2008) were calculated according to INRA (2010).

${ }^{7} \mathrm{FEL}=$ daily intake of fat from extruded linseed supplementation per cow ( $\mathrm{g} / \mathrm{cow}$ per day).

${ }^{8} \mathrm{MY}=$ milk yield, $\mathrm{MFC}=$ milk fat content, $\mathrm{MPC}=$ milk protein content. In bold, significant within study differences $(P<0.05 ;$ when considered individually).

supplemented diets with less than $600 \mathrm{~g}$ of fat from EL were included. This excluded one additional response data; this data set is referred to as the restricted dataset and was used to study all dependent variables except milk FA responses.

\section{RESULTS AND DISCUSSION}

\section{Meta-Design, Internal Consistency, and Reliability of Results}

The data set used to study lactational responses to EL supplementation consisted of 17 publications, 21 trials (i.e., 21 control groups), and 29 EL-supplemented groups (Table 1), most published since 2009. It contained 29 statistical units (i.e., pairs of control and EL-supplemented groups). The FEL was, on average, $472( \pm 297 ; \pm \mathrm{SD}) \mathrm{g} / \mathrm{cow}$ per day and varied from 87 to $1,194 \mathrm{~g}$ (Table 1). The fat content of EL-supplemented diets was, on average, $5.0 \%( \pm 1.59)$ of $\mathrm{DM}$ and varied from 2.3 to $8.4 \%$ of DM. The main forage in the diet was CS for 15, alfalfa hay for 6 , and both grass hay and grass silage for 8 out of 29 pairs of groups. Alfalfa hay was included in the diet for 7 pairs. In about half of the pairs of groups (15 out of 29 ), cows received a low CS-based diet (i.e., 0 to $51 \%$ of total forage) opposed to high CS-based diet (i.e., 75 to 100\% of total forage). 
Additional exclusion criteria were applied on the studies to examine milk FA responses. Data from Brunschwig et al. (1995, 1997, 1998), Egger et al. (2007), Pezzi et al. (2007), Mathieu et al. (2008), and Hurtaud et al. (2012) were excluded due to unknown measure methodologies and insufficiently precise milk FA profiles. Fatty acids data from Gonthier et al. (2005) were also excluded because of low precision that could be explained by the $60-\mathrm{m}$ length of the capillary column used to separate methyl esters compared with the 100$\mathrm{m}$ length used in the studies retained. The data set used to study milk FA responses to EL supplementation consisted of 9 publications, 13 trials (i.e., 13 control groups), and 20 EL-supplemented diets, all published since 2009. Data represented 20 statistical units (i.e., pairs of control and EL-supplemented groups).

The restricted data set, used to study lactational responses to EL supplementation inside a practical range of feeding fat, contained 19 statistical units (i.e., pairs of control and EL-supplemented groups). The FEL was, on average, $286( \pm 107) \mathrm{g} /$ cow per day and varied from 87 to $523 \mathrm{~g}$ (Table 1). The fat content of EL supplemented diets was, on average, $4.1 \%( \pm 0.87)$ of DM and varied from 2.3 to $5.7 \%$ of DM.

The study design was a Latin square for 17 out of the 29 pairs studied (Table 1). Lean et al. (2009) advised avoiding inclusion of Latin square experiments because of possible carryover effects from one period to another and difficulties studying stage of lactation. Duration of fat supplementation (i.e., short-term Latin square trials vs. long-term blocked feeding trials) may furthermore influence lactational (Block and Evans, 2010a) and milk FA responses (Roy et al., 2006). In our study, study design effect (Latin square vs. randomized block), number of animals (total number of animals in the trial and within each experimental group), and duration of feeding fat were tested in each model and found not to be significant for both lactational and milk FA responses. Potential effect of study design on responses to EL supplementation thus was rejected.

To study responses to EL supplementation, the dependent variables were within-experiment differences between supplemented and control groups. As the statistical unit was a pair of 1 control and 1 ELsupplemented group, multiple doses of EL related to the same control could be considered within a doseeffect trial. This induced a clustering effect resulting from multiple comparisons to a single control group within a trial (Rodney et al., 2015). Mixed models including a random study effect were therefore run for comparison purposes, but no differences in estimates were observed (data not shown). Rodney et al. (2015), moreover, indicated that the effect is minor unless very large numbers of repeated comparisons are present in a data set, which was not the case in our study (only 5 trials out of 21).

\section{Intake, Milk Production, and Milk Protein Content Responses to EL Supplementation}

On average, DMI and MY were, respectively, 20.5 $( \pm 2.16)$ and $20.2( \pm 2.47) \mathrm{kg} / \mathrm{d}$ and $29.9( \pm 5.07)$ and $30.1( \pm 5.32) \mathrm{kg} / \mathrm{d}$ in control $(\mathrm{n}=21)$ and EL-supplemented groups $(\mathrm{n}=29)$. Within-study responses (when considered individually) were inconsistent and seldom significant $(P<0.05$; Table 1$)$. The mean of withinstudy DMI responses was not significantly different from zero. However, all DMI within-study responses to supplemented diets with a fat content exceeding $60 \mathrm{~g}$ of fat $/ \mathrm{kg}$ of DM and with a FEL higher than $600 \mathrm{~g} /$ cow per day were negative (with a mean decrease of $1.5 \mathrm{~kg} / \mathrm{d}, \mathrm{n}=9$ ), except one with late-lactation cows in Oeffner et al. (2013; Table 1). The mean of withinstudy MY responses was not different from zero in the whole data set $(\Delta \mathrm{MY}=0.45 \pm 0.546, \mathrm{n}=29 ; P=$ $0.108)$, but was in the restricted data set $(\Delta \mathrm{MY}=0.72$ $\pm 0.549, \mathrm{n}=19 ; P=0.013)$. On the contrary, the mean of within-study $4 \%$ FCM responses was different from zero in the whole data set $(\Delta 4 \% \mathrm{FCM}=-0.68 \pm$ $0.654, \mathrm{n}=29 ; P=0.042)$, but was not in the restricted data set, probably due to the large decrease of MFC with high-fat diets (see further). The mean of withinstudy 4\% FCM:DMI responses was not different from zero in the whole data set, but was different from zero in the restricted data set $(\Delta 4 \%$ FCM:DMI $=-0.034$ $\pm 0.0309, \mathrm{n}=19 ; P=0.033)$. No effect of FEL, diet composition, or other interfering factors was observed on DMI, MY, 4\% FCM, or 4\% FCM:DMI responses (Figure 1).

Block and Evans (2010b), in a literature analysis, reported a mean decrease in DMI in high-fat diet. Rabiee et al. (2012), in a meta-analysis, indicated a significant negative DMI response $(-0.21 \mathrm{~kg} / \mathrm{d})$ and a null MY response to oilseeds supplementation; however, both responses presented a significant high heterogeneity. The heterogeneity could be explained with the differences in FA type within oilseeds and the diversity of control diets in Rabiee et al. (2012). A high proportion of unsaturated lipids could decrease diet digestibility by reducing fiber digestibility and so increase rumen fill (Allen, 2000; Doreau and Ferlay, 2015). Furthermore, they did not exclude control diets with fat supplementation. In our study, the energy level (per $\mathrm{kg}$ of DM) of supplemented diets was higher at high levels of fat inclusion. For the same amount of energy, cows thus needed a lower intake to meet requirements. Finally, DMI was positively correlated with MY response to fats overall (Rabiee et al., 2012). In our study, the en- 

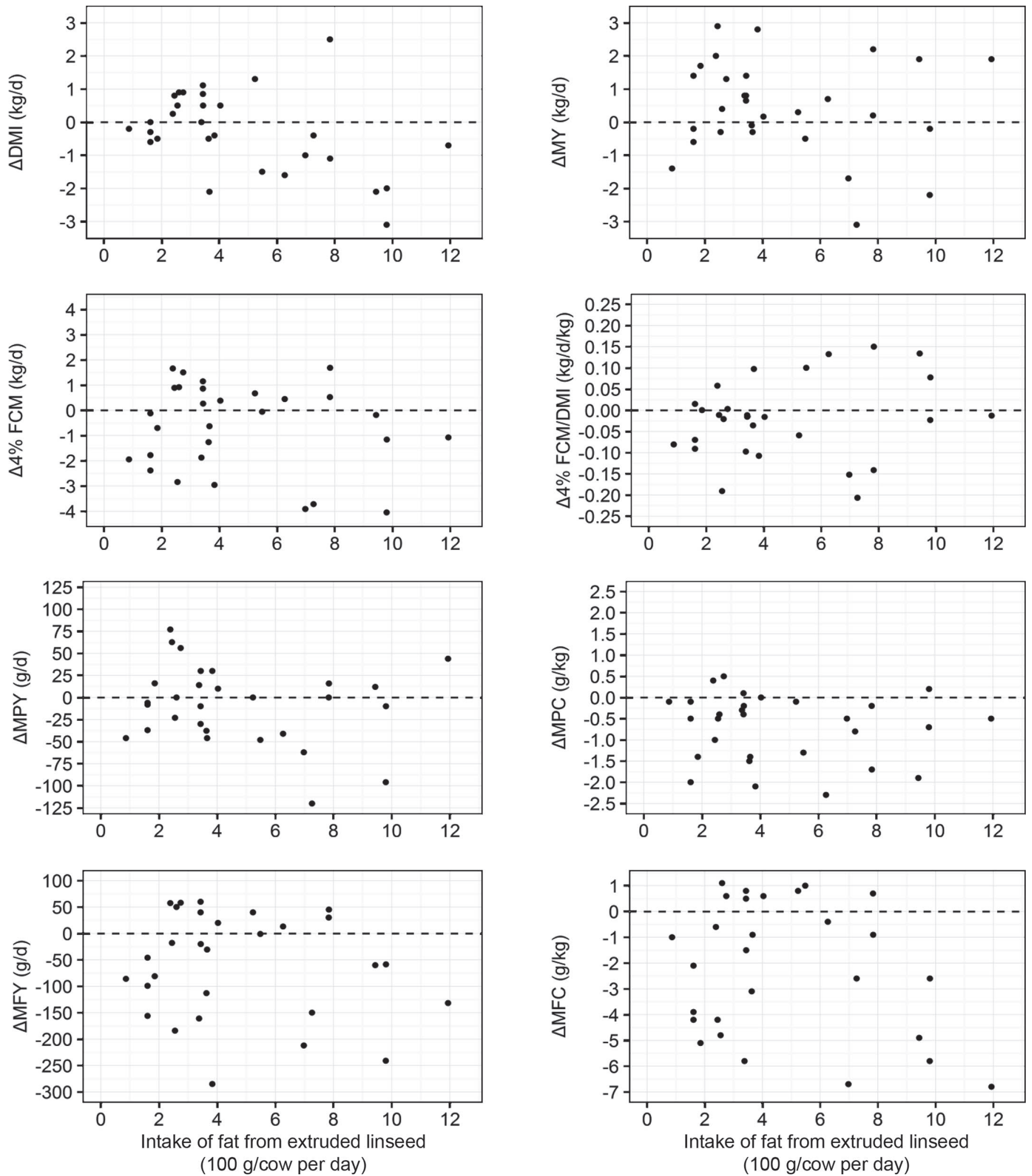

Figure 1. Within-study differences $(\Delta)$ of average DMI (kg/cow per day), milk yield (MY; $\mathrm{kg} / \mathrm{cow}$ per day), $4 \% \mathrm{FCM}$ (kg/cow per day), 4\% FCM:DMI ( $\mathrm{kg}$ of milk/kg of DM per cow per day), milk protein yield (MPY; g/cow per day), milk protein content (MPC; $\mathrm{g} / \mathrm{kg}$ ), milk fat yield (MFY; g/cow per day), and milk fat content (MFC; g/kg) plotted with daily intake of fat from extruded linseed supplementation. For all responses, $\Delta=0$ : dotted line. 
Table 2. Descriptive statistics (mean, SD, minimum, and maximum) of milk fatty acid (FA) composition in the control group and within study responses to extruded linseed (EL) supplementation in dairy cows

\begin{tabular}{|c|c|c|c|c|c|c|c|c|c|c|c|}
\hline Item & $\mathrm{n}_{\mathrm{p}}{ }^{1}$ & $\mathrm{n}_{\mathrm{c}}{ }^{2}$ & \multicolumn{4}{|c|}{ Control } & $\mathrm{n}_{\mathrm{EL}}^{3}$ & \multicolumn{4}{|c|}{$\Delta\left(=\mathrm{FA}_{\mathrm{EL}}-\mathrm{FA}_{\text {control }}\right)$} \\
\hline \multicolumn{12}{|l|}{$\overline{\mathrm{FA}^{4}(\mathrm{~g} / 100 \mathrm{~g} \text { of total } \mathrm{FA})}$} \\
\hline SFA & 9 & 13 & 69.0 & 3.06 & 63.4 & 74.9 & 20 & -10.6 & 6.84 & -24.1 & -0.9 \\
\hline$\Sigma 4: 0$ to $14: 0$ & 9 & 13 & 25.8 & 3.45 & 20.1 & 30.4 & 20 & -5.67 & 4.347 & -14.43 & -0.03 \\
\hline PA $(16: 0)$ & 9 & 13 & 31.9 & 3.07 & 26.0 & 38.1 & 20 & -7.76 & 4.871 & -18.18 & -2.48 \\
\hline MUFA & 9 & 13 & 25.1 & 3.00 & 19.8 & 28.7 & 20 & 8.16 & 5.755 & -0.01 & 19.00 \\
\hline VA (trans-11 18:1) & 6 & 9 & 1.26 & 0.277 & 0.86 & 1.65 & 14 & 1.21 & 1.208 & 0.09 & 3.96 \\
\hline RA (cis-9,trans-11 CLA) & 8 & 11 & 0.56 & 0.143 & 0.30 & 0.77 & 18 & 0.34 & 0.322 & 0.00 & 1.13 \\
\hline PUFA & 9 & 13 & 3.68 & 0.589 & 2.47 & 4.70 & 20 & 2.04 & 1.311 & 0.27 & 4.85 \\
\hline LA (cis-9,cis-12 18:2) & 8 & 12 & 1.75 & 0.306 & 1.35 & 2.30 & 17 & 0.00 & 0.128 & -0.22 & 0.20 \\
\hline ALA (cis-9,cis-12,cis-15 18:3) & 9 & 13 & 0.54 & 0.209 & 0.22 & 1.00 & 20 & 0.59 & 0.321 & 0.21 & 1.23 \\
\hline \multicolumn{12}{|l|}{ Ratio } \\
\hline PA:ALA & 9 & 13 & 71.5 & 41.38 & 26.0 & 173.3 & 20 & -42.5 & 34.50 & -154.3 & -7.5 \\
\hline
\end{tabular}

${ }^{1} \mathrm{n}_{\mathrm{p}}=$ number of publications.

${ }^{2} \mathrm{n}_{\mathrm{c}}=$ number of control groups (i.e., number of trials).

${ }^{3} \mathrm{n}_{\mathrm{EL}}=$ number of extruded linseed supplemented groups.

${ }^{4} 4: 0$ to $14: 0=4: 0+6: 0+8: 0+10: 0+12: 0+14: 0, \mathrm{PA}=$ palmitic acid, OA $=$ oleic acid, $\mathrm{VA}=$ vaccenic acid, $\mathrm{RA}=$ rumenic acid, $\mathrm{LA}=$ linoleic acid, $\mathrm{ALA}=\alpha$-linolenic acid.

ergy spared with the reduction in milk fat synthesis may have contributed to increase MY (Leroy et al., 2014) in the restricted data set, whereas the numerical decrease in DMI with high-fat diets may contribute to the null effect on MY in the whole data set.

On average, MPC was $32.1( \pm 1.83)$ and $31.1( \pm 1.82)$ $\mathrm{g} / \mathrm{kg}$ and MPY was $954( \pm 159.7)$ and $930( \pm 178.8) \mathrm{g} / \mathrm{d}$, respectively, in control $(\mathrm{n}=21)$ and EL-supplemented groups $(\mathrm{n}=29)$. The mean of within-study MPY responses was not different from zero, as observed in Rabiee et al. (2012) for all fat supplementations, but mean of within-study MPC responses was different from zero in both data sets (whole data set: $\triangle \mathrm{MPC}$ $=-0.71 \pm 0.300, \mathrm{n}=29 ; P<0.001 ;$ restricted data set: $\triangle \mathrm{MPC}=-0.58 \pm 0.371, \mathrm{n}=19 ; P=0.004)$. No effect of FEL, diet composition, or other interfering factors was observed on MPY and MPC responses (Figure 1). When studies were considered individually, MPC responses were significantly negative only when corresponding MY responses were significantly positive (Table 1). We can therefore hypothesize that the MPC overall decrease was due to a dilutive effect.

\section{Milk Fat Content and FA Profile Responses to EL Supplementation}

Descriptive statistics of milk FA are presented in Table 2 and milk FA responses to EL supplementation are presented in Table 3 and Figure 2. When considered individually, FA responses were consistent in direction but wide in range (Table 2). The average within-study responses of milk trans-10 18:1 and ALA proportions (i.e., mean of $\Delta$ trans-10 18:1 and $\Delta$ ALA) to EL supplementation were higher than the mean of these milk FA contents in the control group (Table 2). All milk FA responses to FEL were significant $(P<0.001$, Table $3)$, well estimated, and linearly dose-dependent, except the LA response. Intake of fat from extruded linseed explained a large part of the variability of responses (from $54 \%$ for OA response to $91 \%$ for VA response).

Our meta-analysis confirmed that EL supplementation improved the milk FA profile with potentially human health-beneficial FA (Table 3 Figure 2), even with inclusion of modest amount of EL. To illustrate our results, we chose to present the effects for a given amount of EL, namely $400 \mathrm{~g}$ of fat from EL (i.e., $1 \mathrm{~kg}$ of EL), because it is a level of supplementation that is practical to feed in commercial herds and is more sustainable than high-fat diets (Kliem et al., 2016). Indeed, for an intake of $1 \mathrm{~kg}$ of EL (i.e., $400 \mathrm{~g}$ of FEL with an EL fat content equal to $40 \%$ of DM), proportions of SFA, sum of pairs 4:0 to 14:0, and PA decreased by $7.27,3.66$, and $5.57 \mathrm{~g} / 100 \mathrm{~g}$ of total $\mathrm{FA}$, respectively, whereas proportions of MUFA, OA, VA, RA, PUFA, and ALA increased by $5.42,2.99,0.44,0.17,1.41$, and $0.46 \mathrm{~g} / 100$ $\mathrm{g}$ of total FA, respectively. The magnitude of this improvement obviously depends on the milk FA profile before EL supplementation. To qualify the magnitude of these effects, references of milk ALA proportion obtained in 2 systems in western France based on data from commercial farms could be considered. Hurtaud et al. (2014) investigated 10 farms in each system, and 
Table 3. Best fit responses of milk fatty acids (FA; g/100 g of total FA) to daily intake of fat from extruded linseed supplementation (100 g/ cow per day) and according to the forage nature of the diet using the whole data set

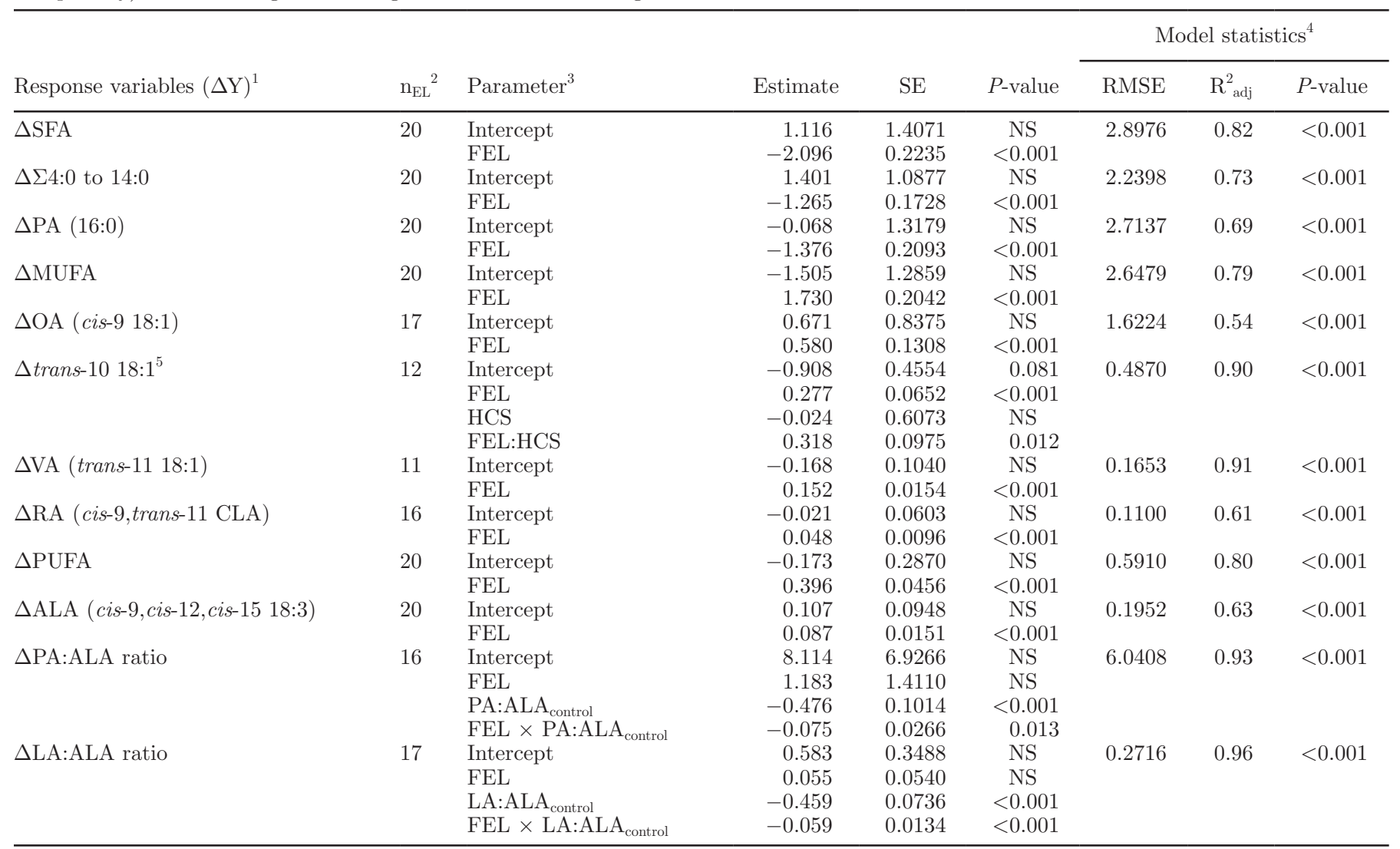

\footnotetext{
${ }^{1} \mathrm{~A}$ response was defined as the difference between the value from the extruded linseed-supplemented group and the control group $\left(\Delta \mathrm{Y}=\mathrm{Y} \mathrm{EL}_{\mathrm{L}}\right.$ $\left.-\mathrm{Y}_{\text {control }}\right) \cdot 4: 0$ to 14:0 $=4: 0+6: 0+8: 0+10: 0+12: 0+14: 0, \mathrm{PA}=$ palmitic acid, $\mathrm{OA}=$ oleic acid, $\mathrm{VA}=$ vaccenic acid, $\mathrm{RA}=$ rumenic acid, $\mathrm{LA}=$ linoleic acid, $\mathrm{ALA}=\alpha$-linolenic acid .

${ }^{2} \mathrm{n}_{\mathrm{EL}}=$ number of extruded linseed-supplemented groups.

${ }^{3} \mathrm{FEL}=$ daily intake of fat from extruded linseed supplementation per cow (100 g/cow per day), LCS = low corn silage-based diet (0 to $51 \%$ of total forage), HCS = high corn silage-based diet (75 to $100 \%$ of total forage).

${ }^{4} \mathrm{RMSE}=$ root mean squared error, $\mathrm{R}_{\text {adj }}^{2}=$ adjusted $\mathrm{R}$-squared .

${ }^{5}$ Subgroups analyses: LCS $\Delta$ trans-10 18:1 = -0.908 + 0.277 $\times$ FEL; HCS $\Delta$ trans $-1018: 1=-0.932+0.595 \times$ FEL .
}

reported an average milk ALA proportion in feeding systems based on CS and herbage of, respectively, 0.44 and $0.78 \mathrm{~g} / 100 \mathrm{~g}$ of total FA. With our models (Table $3)$, we can thus hypothesize that the ALA proportion will be increased by 100 and $50 \%$, respectively, in CS and herbage feeding systems with $1 \mathrm{~kg}$ of EL supplementation. Under this hypothesis, EL supplementation can then be a major way to change the milk FA profile.

Decreases in PA and increase in ALA proportions did not seem to reach a plateau with EL supplementation. No models with a quadratic term in PA and ALA responses were retained, in contrast with findings from a previous meta-analysis on responses to linseeds (Glasser et al., 2008a), although the range of variation in the dose supplemented was similar. The authors hypothesized that ALA response to FEL was curvilinear because of the possible inhibitory effect of a strong decrease in FA de novo synthesis on the incorporation of long-chain FA in milk fat (Glasser et al., 2008a,b). However, milk proportion of FA synthesized de novo also decreased linearly with the dose of EL in our metaanalysis. An increase in the number of data available on EL supplementation since Glasser et al. (2008a) may explain model differences. Moreover, contrary to Glasser et al. (2008a), we focused on responses to EL and not on responses to a pool of different forms of linseed.

Milk trans-10 18:1 proportion was increased by 0.20 to $1.45 \mathrm{~g} / 100 \mathrm{~g}$ of total FA for an intake of $1 \mathrm{~kg}$ of EL (Table 3), depending on the forage composition in the diet. Caution should be taken with trans-10 18:1 proportion in milk regarding questions about its possible negative role in human health (Roy et al., 2007) and, more generally, possible negative effects of total 
trans FA (not studied here; Mozaffarian et al., 2006). However, unlike trans FA from industrial sources, trans FA from ruminant sources were not associated with these negative effects in 2 recent systematic reviews and meta-analysis (Bendsen et al., 2011; de Souza et al., 2015). The value of $0.20 \mathrm{~g}$ of trans-10 18:1 on $100 \mathrm{~g}$ of total FA represents, respectively, 2 and 3 times the average values found in feeding systems based on CS and herbage in the study of Hurtaud et al. (2014).

On average, MFC and MFY were, respectively, 38.1 $( \pm 3.55)$ and $35.6( \pm 4.21) \mathrm{g} / \mathrm{kg}$ and $1,129( \pm 190.5)$ and $1,066( \pm 227.8) \mathrm{g} / \mathrm{d}$ in control $(\mathrm{n}=21)$ and ELsupplemented groups $(\mathrm{n}=29$; Table 1 , Figure 1$)$. Milk fat content and MFY responses were estimated with moderate precision (Table 4). In the whole data set, MFC decreased linearly by $0.30 \mathrm{~g} / \mathrm{kg}$ when FEL increased by $100 \mathrm{~g} / \mathrm{cow}$ per day $(\mathrm{n}=28 ; P=0.031$; Table 4), whereas in the restricted data set no effect
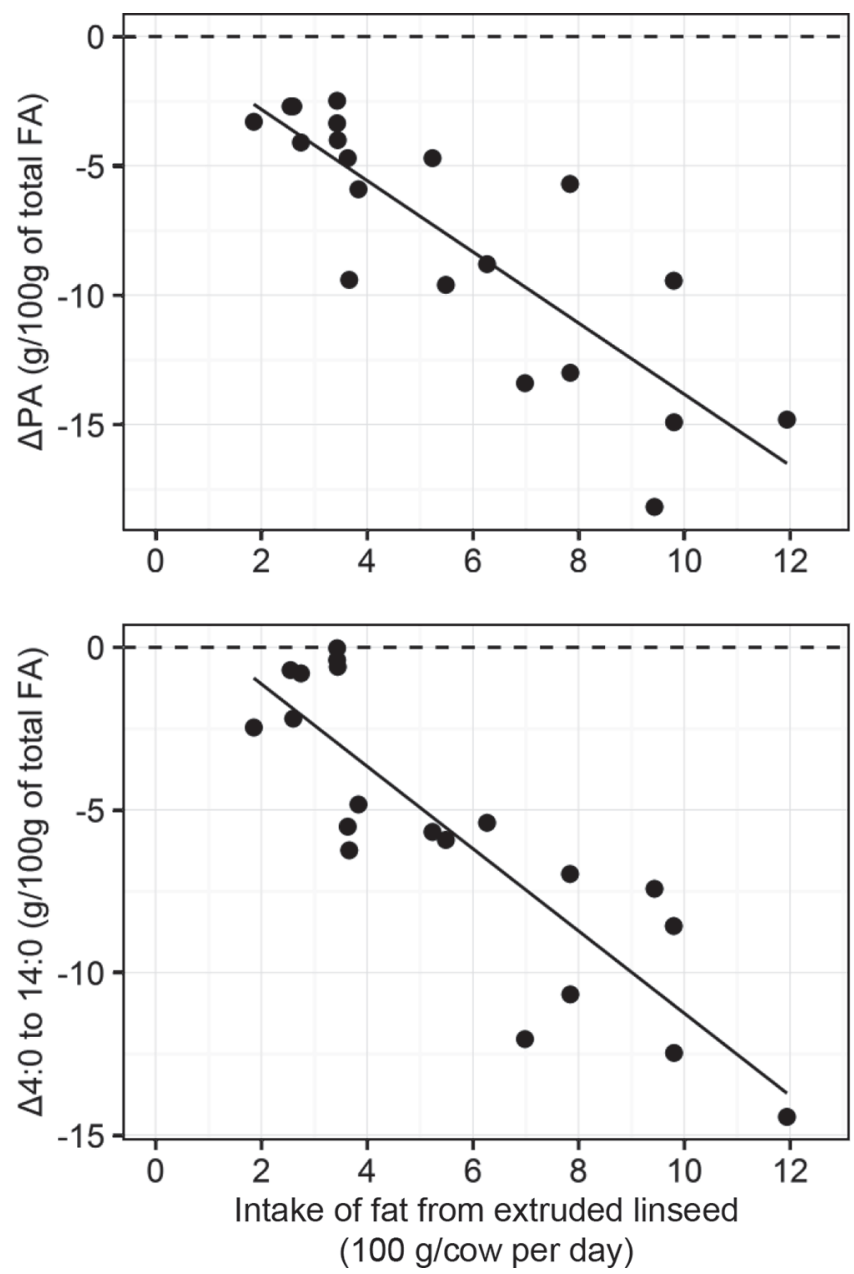

of FEL on MFC was observed. When considering diets supplemented with EL in a practical range of feeding fat to dairy cows (i.e., the restricted data set), MFC did not decrease when FEL increased. No effect of FEL on MFY response was observed in both data sets. Still, our meta-analysis confirmed milk fat depression related to the ruminal biohydrogenation theory with the addition of PUFA to the diet (Shingfield et al., 2010). Both an increase of biohydrogenation intermediates and a decrease in precursors of fat synthesis could be related to the MFC decrease (Bauman and Griinari, 2001, 2003). Indeed, an increase of trans-10 18:1 was associated with low-fat milk syndrome (Bauman and Griinari, 2001, 2003), as it could exert an antilipogenic effect (Shingfield et al., 2010). An increase of trans-10 18:1 was highly correlated with decreases in MFC and MFY in our study (data not shown). Other intermediates of biohydrogenation associated with much evidence to the
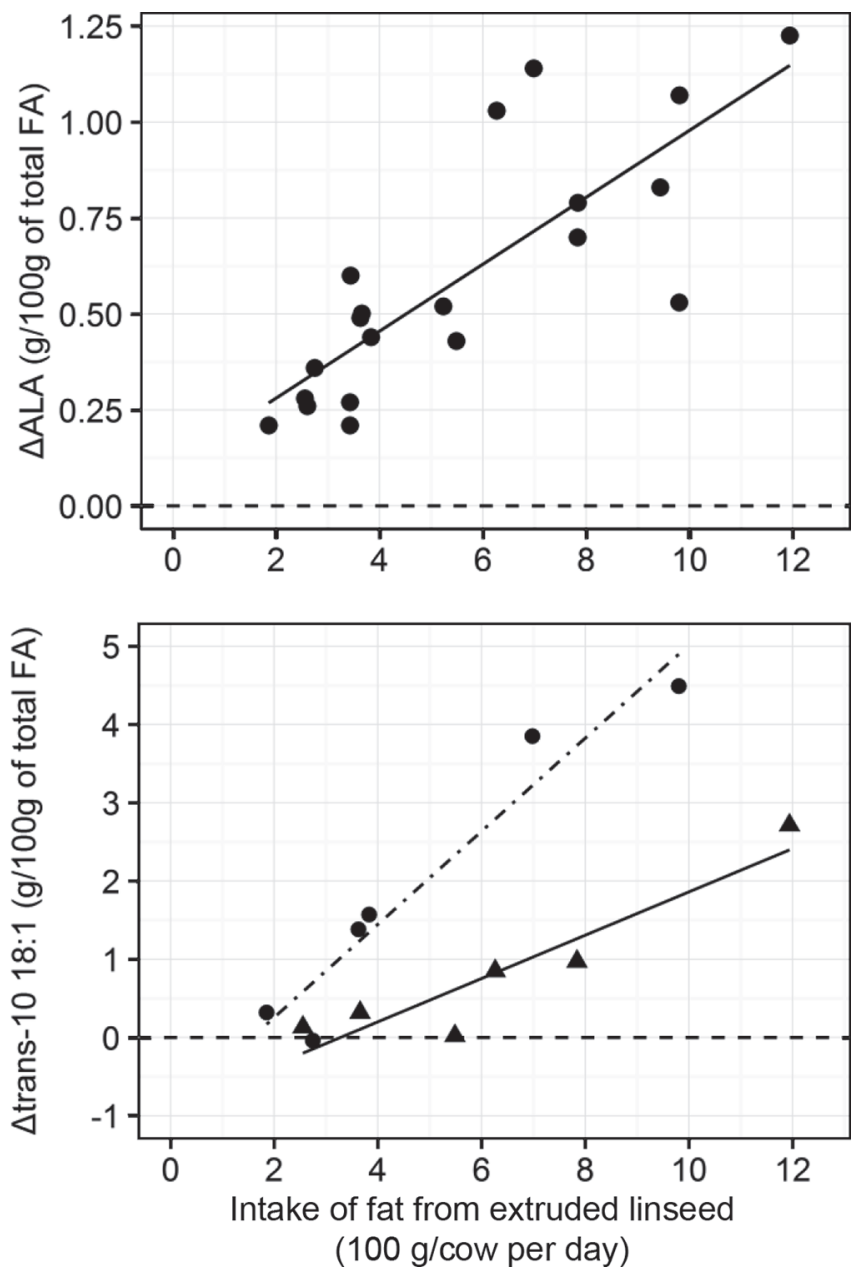

Figure 2. Within-study differences $(\Delta)$ of average proportions in milk of palmitic acid (PA; 16:0), sum of pairs 4:0 to 14:0, $\alpha$-linolenic acid (ALA; cis-9,cis-12,cis-15 18:3), and trans-10 18:1 plotted with daily intake of fat from extruded linseed supplementation. For all responses, $\Delta$ $=0$ : dotted line. For trans-10 18:1 response, LCS $(\mathbf{\Delta})=$ solid line, HCS $(\bullet)=$ dashed and dotted line. LCS $=$ low corn silage-based diet $(0$ to $51 \%$ of total forage), HCS = high corn silage-based diet ( 75 to $100 \%$ of total forage). FA = fatty acids. 
Table 4. Best fit responses of milk fat content $(\mathrm{g} / \mathrm{kg})$ and milk fat yield $(\mathrm{g} / \mathrm{d})$ and to daily intake of fat from extruded linseed (EL) supplementation (100 g/cow per day) and according to the forage nature of the diet using the whole and the restricted data sets

\begin{tabular}{|c|c|c|c|c|c|c|c|c|}
\hline \multirow{2}{*}{$\begin{array}{l}\text { Response variables } \\
(\Delta \mathrm{Y})^{1}\end{array}$} & \multirow[b]{2}{*}{$\mathrm{n}_{\mathrm{EL}}^{2}$} & \multirow[b]{2}{*}{ Parameter $^{3}$} & \multirow[b]{2}{*}{ Estimate } & \multirow[b]{2}{*}{$\mathrm{SE}$} & \multirow[b]{2}{*}{$P$-value } & \multicolumn{3}{|c|}{ Model statistics ${ }^{4}$} \\
\hline & & & & & & RMSE & $\mathrm{R}_{\text {adj }}^{2}$ & $P$-value \\
\hline \multirow[t]{9}{*}{$\Delta \mathrm{MFC}$} & \multirow[t]{3}{*}{28} & Intercept & 0.68 & 0.858 & NS & \multirow[t]{3}{*}{2.038} & \multirow[t]{3}{*}{0.39} & \multirow[t]{3}{*}{$<0.001$} \\
\hline & & FEL & -0.30 & 0.131 & 0.031 & & & \\
\hline & & HCS & -3.15 & 0.781 & $<0.001$ & & & \\
\hline & \multirow[t]{2}{*}{28} & Intercept & -3.03 & 0.482 & $<0.001$ & \multirow[t]{2}{*}{2.208} & \multirow[t]{2}{*}{0.28} & \multirow[t]{2}{*}{0.002} \\
\hline & & Alfalfa (presence) & 3.29 & 0.964 & 0.002 & & & \\
\hline & \multirow[t]{2}{*}{18} & Intercept & -0.44 & 0.652 & NS & \multirow[t]{2}{*}{1.955} & \multirow[t]{2}{*}{0.32} & \multirow[t]{2}{*}{0.009} \\
\hline & & HCS & -2.76 & 0.922 & 0.009 & & & \\
\hline & \multirow[t]{2}{*}{18} & Intercept & -2.83 & 0.555 & $<0.001$ & \multirow[t]{2}{*}{1.922} & \multirow[t]{2}{*}{0.34} & \multirow[t]{2}{*}{0.006} \\
\hline & & Alfalfa (presence) & 3.01 & 0.961 & 0.006 & & & \\
\hline \multirow[t]{6}{*}{$\Delta \mathrm{MFY}$} & \multirow[t]{2}{*}{29} & Intercept & -90 & 17.8 & $<0.001$ & \multirow[t]{2}{*}{83.4} & \multirow[t]{2}{*}{0.29} & \multirow[t]{2}{*}{0.002} \\
\hline & & Alfalfa (presence) & 127 & 36.2 & 0.002 & & & \\
\hline & \multirow[t]{2}{*}{19} & Intercept & 4 & 28.5 & NS & \multirow[t]{2}{*}{85.6} & \multirow[t]{2}{*}{0.24} & \multirow[t]{2}{*}{0.019} \\
\hline & & HCS & -102 & 39.3 & 0.019 & & & \\
\hline & \multirow[t]{2}{*}{18} & Intercept & -75 & 18.4 & 0.001 & \multirow[t]{2}{*}{63.8} & \multirow[t]{2}{*}{0.40} & 0.003 \\
\hline & & Alfalfa (presence) & 113 & 31.9 & 0.003 & & & \\
\hline
\end{tabular}

${ }^{1} \mathrm{~A}$ response was defined as the difference between the value from the extruded linseed-supplemented group and the control group $\left(\Delta \mathrm{Y}=\mathrm{Y}_{\mathrm{EL}}-\mathrm{Y}_{\text {control }}\right) . \mathrm{MFC}=$ milk fat content; MFY = milk fat yield.

${ }^{2} \mathrm{n}_{\mathrm{EL}}=$ number of supplemented diets with extruded linseed. In italics, data issued from the restricted data set including only diets with $<60 \mathrm{~g}$ of fat $/ \mathrm{kg}$ of DM and supplemented with $<600 \mathrm{~g}$ of fat from extruded linseed.

${ }^{3} \mathrm{FEL}=$ daily intake of fat from extruded linseed supplementation per cow $(100 \mathrm{~g} / \mathrm{cow}$ per day $)$, LCS = low corn silage-based diet (0 to $51 \%$ of total forage), HCS = high corn silage-based diet ( 75 to $100 \%$ of total forage).

${ }^{4} \mathrm{RMSE}=$ root mean squared error, $\mathrm{R}_{\text {adj }}^{2}=$ adjusted $\mathrm{R}$-squared.

decrease of MFC, such as trans-10,cis-12 CLA (Baumgard et al., 2000), were not studied in our meta-analysis due to the limited available data in our data set. The contribution of a decrease of the substrates, acetate, and butyrate used to synthesize fat in the udder (especially sum of pairs 4:0 to 14:0) in the MFC drop cannot be excluded. Indeed, EL decreased linearly butyrate in hay-based diets and acetate and butyrate in CS-based diets, whereas propionate was increased, resulting in a shift of rumen fermentation patterns (Martin et al., 2016).

Extrusion may have played a role in the formation of biohydrogenation intermediates responsible for the decrease in MFC. We hypothesized, in the introduction, that extrusion may protect UFA from ruminal biohydrogenation (Kennelly, 1996; Doreau et al., 2009); the linear increase of milk in ALA content confirmed that hypothesis, even if the efficiency of extrusion to protect fat in comparison with other processes is inconsistent in the literature (Dang Van et al., 2011; Troegeler-Meynadier et al., 2014). A decrease in ALA biohydrogenation was generally observed, as well as an increase in biohydrogenation intermediates (Dang Van et al., 2011; Troegeler-Meynadier et al., 2014). Indeed, in a study comparing efficiency of the soybean heating process including extrusion on ruminal biohydrogenation, Troegeler-Meynadier et al. (2014) concluded that extrusion is the most efficient thermal treatment to op- timize CLA content. However, 2 biohydrogenation pathways coexist in the rumen, trans-10 and trans-11, leading to 2 distinct CLA, respectively, the trans-10,cis-12 CLA, implied in MFC decrease, and RA, which has no effect on MFC (Baumgard et al., 2000; Shingfield et al., 2010). The importance of each biohydrogenation pathway depends on the microbial population of the rumen influenced by the composition of the diet (Pottier et al., 2006; Jenkins et al., 2008; Zened et al., 2013). We can conclude that extrusion protected PUFA of linseed from ruminal biohydrogenation favored biohydrogenation intermediates, but that the type of biohydrogenation intermediates was influenced by the composition of the diet. Finally, the efficacy of protection of linseed fat against ruminal biohydrogenation by extrusion seems dependent on the preconditioning of seeds before extrusion and on the conditions of the extrusion process (Doreau et al., 2009; Sterk et al., 2010, 2012). However, we were not able to test the conditions of the extrusion process as a potential interfering factor.

\section{Influence of Diet Composition on Responses to EL Supplementation}

Surprisingly, no effect of diet composition was observed on milk FA responses to EL supplementation, except an effect of the proportion of corn silage in total forage on trans-10 18:1 response (Table 3, Figure 2). As 
a consequence, in commercial farms, the evolution of the milk FA profile after EL supplementation would be predictable with only the amounts of EL added to the diet no matter the nature of the diet. This result could have direct implications for advice given to farmers to reach target values of some milk FA proportions if any price compensation or a premium price was implemented to reward farmers for producing milk with a better nutritional quality based on the milk FA profile. However, this result should be used cautiously, as interactions between forage source, forage-to-concentrate ratio, chemical composition of the diet, and oilseed supplementation with milk FA evolution (other than trans-10 18:1) were demonstrated in many studies (Dewhurst et al., 2006; Chilliard et al., 2007; Kliem and Shingfield, 2016).

The variability of MFC and MFY responses was explained by the forage nature in the diet in almost all models (Table 4). Extruded linseed supplementation associated with high CS-based diet decreased MFC by $3.2 \mathrm{~g} / \mathrm{kg}(\mathrm{n}=28 ; P<0.001)$. When the diet contained alfalfa hay, EL supplementation did not decrease MFC, whereas when the diet did not contain alfalfa hay, EL supplementation decreased MFC by $3.0 \mathrm{~g} / \mathrm{kg}(\mathrm{n}=28$; $P=0.002$ ). In the restricted data set, the effects of CS and alfalfa hay on MFC were similar to those observed in the whole data set $(\mathrm{n}=18 ; P=0.009$ and 0.006 , respectively). In the whole data set, when the diet contained alfalfa hay, EL supplementation had no effect on MFY, whereas when the diet did not contain alfalfa hay, EL supplementation decreased MFY by $90 \mathrm{~g} / \mathrm{d}$ $(\mathrm{n}=29 ; P=0.002)$. No effect of proportion of CS was observed in the whole data set. In the restricted data set, effect of alfalfa hay on MFY response was similar but EL supplementation associated with high CS-based diet decreased MFY by $102 \mathrm{~g} / \mathrm{d}$ ( $\mathrm{n}=19 ; P=$ 0.019). Finally, the response of the milk trans-10 18:1 proportion to the increase of FEL was higher with high CS-based diet than with low CS-based diet $(\mathrm{n}=12 ; P$ $<0.001$; adjusted $\left.\mathrm{R}^{2}=0.90\right)$.

We hypothesized that the effect of CS proportion in forage on MFC response was related to the differential trans-10 18:1 response according to CS proportion, along with a putative decrease of acetate and butyrate substrates (Martin et al., 2016). Influence of corn silage proportion on trans-10 18:1 has 2 implications. First, EL supplementation associated with a high CS-based diet should be made with caution to avoid increasing this potentially human health-deleterious FA in milk. Second, the increase of trans-10 18:1 proportion in milk may reflect a more important disturbance on rumen fermentation patterns and a lower rumen $\mathrm{pH}$ with a high CS-based diet rather than a low CS-based diet (Weimer et al., 2010; Kliem and Shingfield, 2016). In- deed, this may denote a modification of the composition or activity of rumen flora (Weimer et al., 2010; Zened et al., 2013) with EL supplementation in interaction with CS proportion in forage. As suggested by Zened et al. (2013), it can be hypothesized that the activity of cellulolytic bacteria, responsible for producing trans-11 18:1, was inhibited or the population decreased, or bacteria responsible for producing trans-10 18:1 were stimulated, leading to a novel microbial equilibrium in the rumen when feeding EL with high CS-based diet.

The trans-10 18:1 biohydrogenation pathway can occur only if there is a LA source in the diet and ALA being hydrogenated in VA (Zened et al., 2011). Extruded linseed contains small amounts of LA, whereas LA is the major FA (i.e., $45.8 \mathrm{~g} / 100 \mathrm{~g}$ of total FA) in corn silage (Glasser et al., 2013). Inclusion of CS in the diet thus supplied LA for shift in trans-10 biohydrogenation pathway. Finally, an interaction between the proportion of CS in total forage and FEL was observed for the trans-10 18:1 response (Table 3, Figure 2). We can hypothesize that FEL increased trans-10 18:1 production because of toxic effect of PUFA, in particular ALA, on rumen bacteria implied in the trans-11 18:1 biohydrogenation pathway (Maia et al., 2010), even if Martin et al. (2016) did not notice modifications in concentrations of several cellulolytic bacteria with increasing supply of EL.

In our study, we were not able to display any effect of the forage-to-concentrate ratio or the NDF and starch contents of the diets. Loor et al. (2004) suggested that high-concentrate diets enhanced trans-10 18:1 production in the rumen, and Sterk et al. (2011), when feeding crushed linseed, observed that milk FA profile was influenced by the proportion of the concentrates. This may be due to the limited available data on trans-10 18:1 proportion $(\mathrm{n}=12)$ and not enough variation in forage levels and chemical characteristics of the diet between studies. Furthermore, NDF and starch digestibility were not studied.

Interestingly, the presence of alfalfa hay prevented a decrease in MFC after EL supplementation. This result is in accordance with the finding of Onetti and Grummer (2004), who studied lactational responses of dairy cows to 3 fat supplements as affected by the ratio of alfalfa to CS in the diet through a meta-analysis of the literature. Tallow decreased MFC and MFY when associated with a CS-based diet (60\% or more of forage), but not with an alfalfa (60\% or more of forage was alfalfa hay or alfalfa silage) or a mixed (ratio of alfalfa and CS from 41:59 to 59:41) diet (Onetti and Grummer, 2004). These effects were not observed for rumen-inert fat sources, as expected by those authors. Moreover, replacing CS by alfalfa hay overcame MFC depression after cottonseed or tallow supplementation in another 
study (Smith et al., 1993). Presence of alfalfa hay could not be studied in trans-10 18:1 response due to lack of data. However, we can hypothesize that supply of LA and starch was decreased with the presence of alfalfa hay in the forage. Then, alfalfa hay could have acted as a buffer in the rumen with specific agents, increasing fiber content and average particle size of the diet, thus preventing from a decrease in rumen $\mathrm{pH}$. In conclusion, addition of alfalfa hay to the diet may have led to favorable rumen conditions for the growth and activity of cellulolytic bacteria in the rumen at the expense of other bacteria implicated in MFC decrease.

\section{CONCLUSIONS}

Despite the limited available published data, a rigorous review of papers on EL supplementation to dairy cows to select homogeneous data enabled us to obtain reliable results. Our meta-analysis highlighted that the responses of milk FA profile to EL supplementation were linearly dose-dependent. On the contrary, no effect of the dose of EL on DMI, MY, and milk components was observed with an EL supplementation inside a practical range of feeding fat to dairy cows. The study of milk FA suggested that ruminal fermentation patterns and biohydrogenation pathways seem to be disturbed when EL was associated with high corn silage-based diets, leading to a significant drop in MFC. However, inclusion of alfalfa hay in the diet may have avoided these perturbations. When supplementing EL inside a practical range of feeding fat to dairy cows, the milk FA profile was improved with increased potentially human health-beneficial FA (OA, VA, RA, ALA, and PUFA) and decreased PA and SFA, along with minor changes in animal performance.

\section{ACKNOWLEDGMENTS}

The authors acknowledge S. Couvreur (Ecole Supérieure d'Agricultures, Angers, France) and A. Madouasse (BIOEPAR, INRA, Oniris, Nantes, France) for helpful discussions respectively on milk fatty acid data and $\mathrm{R}$ programming. We also acknowledge L. Delaby and C. Hurtaud (PEGASE, INRA, Agrocampus-Ouest, SaintGilles, France) for helpful discussions on the writing of this paper. We also acknowledge Valorex (Combourtillé, France), Terrena (Ancenis, France) and Association Nationale de la Recherche et de la Technologie (ANRT, Paris, France) for financial support of a PhD studentship.

\section{REFERENCES}

Allen, M. S. 2000. Effects of diet on short-term regulation of feed intake by lactating dairy cattle. J. Dairy Sci. 83:1598-1624. https:// doi.org/10.3168/jds.S0022-0302(00)75030-2.
Barceló-Coblijn, G., and E. J. Murphy. 2009. Alpha-linolenic acid and its conversion to longer chain $n-3$ fatty acids: Benefits for human health and a role in maintaining tissue $n-3$ fatty acid levels. Prog. Lipid Res. 48:355-374. https://doi.org/10.1016/j. plipres.2009.07.002.

Bauman, D., and J. Griinari. 2001. Regulation and nutritional manipulation of milk fat: low-fat milk syndrome. Livest. Prod. Sci 70:15-29. https://doi.org/10.1016/S0301-6226(01)00195-6.

Bauman, D. E., and J. M. Griinari. 2003. Nutritional regulation of milk fat synthesis. Annu. Rev. Nutr. 23:203-227. https://doi. org/10.1146/annurev.nutr.23.011702.073408.

Baumgard, L. H., B. A. Corl, D. A. Dwyer, A. Saebø, and D. E. Bauman. 2000. Identification of the conjugated linoleic acid isomer that inhibits milk fat synthesis. Am. J. Physiol. Regul. Integr. Comp. Physiol. 278:R179-R184.

Bendsen, N. T., R. Christensen, E. M. Bartels, and A. Astrup. 2011 Consumption of industrial and ruminant trans fatty acids and risk of coronary heart disease: A systematic review and meta-analysis of cohort studies. Eur. J. Clin. Nutr. 65:773-783. https://doi. org $/ 10.1038 /$ ejcn.2011.34

Block, E., and E. Evans. 2010a. A model to compare the effects of fat sources upon performance and dry matter intake: Effects of trial duration. J. Dairy Sci. 93(E-Suppl. 1):440. (Abstr.)

Block, E., and E. Evans. 2010b. A model to compare effects of supplemental fat sources on performance and dry matter intake in dairy cows: Effects of fat inclusion level. J. Dairy Sci. 93(E-Suppl. 1):440. (Abstr.)

Brunschwig, P., P. Augeard, P. Weill, and Y. Chilliard. 1995. Effects of feeding concentrate including fat to dairy cows fed maize silage. Pages 215-218 in Proc. 2nd Rencontres Autour des Recherches sur les Ruminants, Paris, France. Institut de l'Elevage, INRA, Paris, France.

Brunschwig, P., P. Kernen, and P. Weill. 1997. Effects of feeding concentrate including polyunsaturated fat acids to dairy cows fed maize silage. Page 361 in Proc. 4th Rencontres Autour des Recherches sur les Ruminants, Paris, France. Institut de l'Elevage, INRA, Paris, France.

Brunschwig, P., P. Kernen, and P. Weill. 1998. Effects of supplementation including polyunsaturated fat acids on dairy performances of cows in middle lactation. Page 262 in Proc. 5th Rencontres Autour des Recherches sur les Ruminants, Paris, France. Institut de l'Elevage, INRA, Paris, France.

Chilliard, Y., F. Glasser, A. Ferlay, L. Bernard, J. Rouel, and M. Doreau. 2007. Diet, rumen biohydrogenation and nutritional quality of cow and goat milk fat. Eur. J. Lipid Sci. Technol. 109:828855. https://doi.org/10.1002/ejlt.200700080.

Chilliard, Y., C. Martin, J. Rouel, and M. Doreau. 2009. Milk fatty acids in dairy cows fed whole crude linseed, extruded linseed, or linseed oil, and their relationship with methane output. J. Dairy Sci. 92:5199-5211. https://doi.org/10.3168/jds.2009-2375.

Dang Van, Q. C., L. Bejarano, E. Mignolet, D. Coulmier, E. Froidmont, Y. Larondelle, and M. Focant. 2011. Effectiveness of extruded rapeseed associated with an alfalfa protein concentrate in enhancing the bovine milk fatty acid composition. J. Dairy Sci. 94:4005-4015. https://doi.org/10.3168/jds.2011-4204.

de Souza, R. J., A. Mente, A. Maroleanu, A. I. Cozma, V. Ha, T. Kishibe, E. Uleryk, P. Budylowski, H. Schünemann, J. Beyene, and S. S. Anand. 2015. Intake of saturated and trans unsaturated fatty acids and risk of all cause mortality, cardiovascular disease, and type 2 diabetes: Systematic review and meta-analysis of observational studies. BMJ 351:h3978 https://doi.org/10.1136/bmj. h3978.

Dewhurst, R. J., K. J. Shingfield, M. R. F. Lee, and N. D. Scollan 2006. Increasing the concentrations of beneficial polyunsaturated fatty acids in milk produced by dairy cows in high-forage systems. Anim. Feed Sci. Technol. 131:168-206. https://doi.org/10.1016/j. anifeedsci.2006.04.016.

Doreau, M., and A. Ferlay. 2015. Linseed: A valuable feedstuff for ruminants. OCL 22:D611. https://doi.org/10.1051/ocl/2015042.

Doreau, M., S. Laverroux, J. Normand, G. Chesneau, and F. Glasser. 2009. Effect of linseed fed as rolled seeds, extruded seeds or oil on 
fatty acid rumen metabolism and intestinal digestibility in cows. Lipids 44:53-62. https://doi.org/10.1007/s11745-008-3250-x.

Egger, P., G. Holzer, S. Segato, E. Werth, F. Schwienbacher, G. Peratoner, I. Andrighetto, and A. Kasal. 2007. Effects of oilseed supplements on milk production and quality in dairy cows fed a hay-based diet. Ital. J. Anim. Sci. 6:395. https://doi.org/10.4081/ ijas.2007.395.

Ferlay, A., M. Doreau, C. Martin, and Y. Chilliard. 2013. Effects of incremental amounts of extruded linseed on the milk fatty acid composition of dairy cows receiving hay or corn silage. J. Dairy Sci. 96:6577-6595. https://doi.org/10.3168/jds.2013-6562.

Ferlay, A., B. Martin, S. Lerch, M. Gobert, P. Pradel, and Y. Chilliard. 2010. Effects of supplementation of maize silage diets with extruded linseed, vitamin $\mathrm{E}$ and plant extracts rich in polyphenols, and morning v. evening milking on milk fatty acid profiles in Holstein and Montbéliarde cows. Animal 4:627. https://doi.org/10.1017/ S1751731109991224.

Glasser, F., M. Doreau, G. Maxin, and R. Baumont. 2013. Fat and fatty acid content and composition of forages: A meta-analysis. Anim. Feed Sci. Technol. 185:19-34. https://doi.org/10.1016/j. anifeedsci.2013.06.010.

Glasser, F., A. Ferlay, and Y. Chilliard. 2008a. Oilseed lipid supplements and fatty acid composition of cow milk: A meta-analysis. J. Dairy Sci. 91:4687-4703. https://doi.org/10.3168/jds.2008-0987.

Glasser, F., A. Ferlay, M. Doreau, P. Schmidely, D. Sauvant, and Y. Chilliard. 2008b. Long-chain fatty acid metabolism in dairy cows: A meta-analysis of milk fatty acid yield in relation to duodenal flows and de novo synthesis. J. Dairy Sci. 91:2771-2785. https:// doi.org/10.3168/jds.2007-0383.

Glasser, F., P. Schmidely, D. Sauvant, and M. Doreau. 2008c. Digestion of fatty acids in ruminants: A meta-analysis of flows and variation factors: 2. C18 fatty acids. Animal 2:691-704. https:// doi.org/10.1017/S1751731108002036.

Gonthier, C., A. F. Mustafa, D. R. Ouellet, P. Y. Chouinard, R. Berthiaume, and H. V. Petit. 2005. Feeding micronized and extruded flaxseed to dairy cows: Effects on blood parameters and milk fatty acid composition. J. Dairy Sci. 88:748-756. https://doi. org/10.3168/jds.S0022-0302(05)72738-7.

Hurtaud, C., S. Buchin, F. Berodier, G. Duboz, and E. Beuvier. 2012. Effect of mixtures of food rich in omega 3 fatty acids on milk fatty acid composition and on physiochemical and sensory characteristics of hard cooked cheeses. Page 418 in Proc. 19th Rencontres Autour des Recherches sur les Ruminants, Paris, France. Institut de l'Elevage, INRA, Paris, France.

Hurtaud, C., G. Chesneau, D. Coulmier, and J. L. Peyraud. 2013. Effects of extruded linseed or alfalfa protein concentrate in interaction with two levels of concentrates on milk production and composition in dairy cows. Livest. Sci. 158:64-73. https://doi. org/10.1016/j.livsci.2013.10.002

Hurtaud, C., M. Dutreuil, M. Coppa, C. Agabriel, and B. Martin. 2014. Characterization of milk from feeding systems based on herbage or corn silage with or without flaxseed and authentication through fatty acid profile. Dairy Sci. Technol. 94:103-123. https:// doi.org/10.1007/s13594-013-0147-0.

Hurtaud, C., F. Faucon, S. Couvreur, and J.-L. Peyraud. 2010. Linear relationship between increasing amounts of extruded linseed in dairy cow diet and milk fatty acid composition and butter properties. J. Dairy Sci. 93:1429-1443. https://doi.org/10.3168/jds.20092839.

INRA. 2010. Alimentation des bovins, ovins et caprins-Besoins des animaux-Valeurs des aliments. Tables INRA 2007. Mise à jour 2010. Editions Quae. Versailles, France.

Jenkins, T. C. 1997. Success of fat in dairy rations depends on the amount. Feedstuffs 69:11-12.

Jenkins, T. C., R. J. Wallace, P. J. Moate, and E. E. Mosley. 2008. Board-invited review: Recent advances in biohydrogenation of unsaturated fatty acids within the rumen microbial ecosystem. J. Anim. Sci. 86:397-412. https://doi.org/10.2527/jas.2007-0588.

Kennelly, J. J. 1996. The fatty acid composition of milk fat as influenced by feeding oilseeds. Anim. Feed Sci. Technol. 60:137-152.
Kliem, K.E., D.J. Humphries, C.K. Reynolds, R. Morgan, and D.I. Givens. 2016. Effect of oilseed type on milk fatty acid composition of individual cows, and also bulk tank milk fatty acid composition from commercial farms. Animal 11:354-364. https://doi. org/10.1017/S1751731116001403.

Kliem, K. E., and K. J. Shingfield. 2016. Manipulation of milk fatty acid composition in lactating cows: Opportunities and challenges. Eur. J. Lipid Sci. Technol. 118:1661-1683. https://doi. org/10.1002/ejlt.201400543.

Lean, I. J., A. R. Rabiee, T. F. Duffield, and I. R. Dohoo. 2009. Invited review: Use of meta-analysis in animal health and reproduction: Methods and applications. J. Dairy Sci. 92:3545-3565. https://doi. org/10.3168/jds.2009-2140.

Lerch, S., A. Ferlay, D. Pomiès, B. Martin, J. A. A. Pires, and Y. Chilliard. 2012. Rapeseed or linseed supplements in grass-based diets: Effects on dairy performance of Holstein cows over 2 consecutive lactations. J. Dairy Sci. 95:1956-1970. https://doi.org/10.3168/ jds.2011-4575.

Leroy, J. L., R. Sturmey, V. Van Hoeck, J. De Bie, P. McKeegan, and P. Bols. 2014. Dietary fat supplementation and the consequences for oocyte and embryo quality: Hype or significant benefit for dairy cow reproduction? Reprod. Domest. Anim. 49:353-361. https://doi.org/10.1111/rda.12308.

Livingstone, K. M., D. J. Humphries, P. Kirton, K. E. Kliem, D. I. Givens, and C. K. Reynolds. 2015. Effects of forage type and extruded linseed supplementation on methane production and milk fatty acid composition of lactating dairy cows. J. Dairy Sci. 98:4000-4011. https://doi.org/10.3168/jds.2014-8987.

Loor, J. J., K. Ueda, A. Ferlay, Y. Chilliard, and M. Doreau. 2004. Biohydrogenation, duodenal flow, and intestinal digestibility of trans fatty acids and conjugated linoleic acids in response to dietary forage:concentrate ratio and linseed oil in dairy cows. J. Dairy Sci. 87:2472-2485. https://doi.org/10.3168/jds.S0022-0302(04)73372$\mathrm{X}$

Maia, M. R., L. C. Chaudhary, C. S. Bestwick, A. J. Richardson, N. McKain, T. R. Larson, I. A. Graham, and R. J. Wallace. 2010. Toxicity of unsaturated fatty acids to the biohydrogenating ruminal bacterium, Butyrivibrio fibrisolvens. BMC Microbiol. 10:52. https://doi.org/10.1186/1471-2180-10-52.

Martin, C., A. Ferlay, P. Mosoni, Y. Rochette, Y. Chilliard, and M. Doreau. 2016. Increasing linseed supply in dairy cow diets based on hay or corn silage: Effect on enteric methane emission, rumen microbial fermentation, and digestion. J. Dairy Sci. 99:3445-3456. https://doi.org/10.3168/jds.2015-10110.

Mathieu, Y., M. Fougere, Y. Bergot, P. Dermerle, P. Brunschwig, and V. Chatellier. 2008. Effect of extruded linseed concentrate on the milk content and production of dairy cows. Page 117 in Proc. 15th Rencontres Autour des Recherches sur les Ruminants, Paris, France. Institut de l'Elevage, INRA, Paris, France.

Mozaffarian, D., M. B. Katan, A. Ascherio, M. J. Stampfer, and W. C. Willett. 2006. Trans fatty acids and cardiovascular disease. N. Engl. J. Med. 354:1601-1613. https://doi.org/10.1056/NEJMra054035.

Neveu, C., B. Baurhoo, and A. Mustafa. 2013. Effect of feeding extruded flaxseed with different forage:concentrate ratios on the performance of dairy cows. J. Dairy Sci. 96:3886-3894. https://doi. org/10.3168/jds.2012-6189.

Neveu, C., B. Baurhoo, and A. Mustafa. 2014. Effect of feeding extruded flaxseed with different grains on the performance of dairy cows and milk fatty acid profile. J. Dairy Sci. 97:1543-1551. https://doi.org/10.3168/jds.2013-6728.

Oeffner, S. P., Y. Qu, J. Just, N. Quezada, E. Ramsing, M. Keller, G. Cherian, L. Goddick, and G. Bobe. 2013. Effect of flaxseed supplementation rate and processing on the production, fatty acid profile, and texture of milk, butter, and cheese. J. Dairy Sci. 96:1177-1188. https://doi.org/10.3168/jds.2012-5941.

Onetti, S. G., and R. R. Grummer. 2004. Response of lactating cows to three supplemental fat sources as affected by forage in the diet and stage of lactation: A meta-analysis of literature. Anim. Feed Sci. Technol. 115:65-82. https://doi.org/10.1016/j. anifeedsci.2004.02.009. 
Palmquist, D. L., A. Denise Beaulieu, and D. M. Barbano. 1993. Feed and animal factors influencing milk fat composition. J. Dairy Sci. 76:1753-1771. https://doi.org/10.3168/jds.S0022-0302(93)775086.

Palmquist, D. L., and T. C. Jenkins. 1980. Fat in lactation rations. J. Dairy Sci. 63:1-14. https://doi.org/10.3168/jds.S00220302(80)82881-5 (Review).

Petit, H. V. 2010. Review: Feed intake, milk production and milk composition of dairy cows fed flaxseed. Can. J. Anim. Sci. 90:115-127. https://doi.org/10.4141/CJAS09040.

Pezzi, P., M. Giammarco, G. Vignola, and N. Brogna. 2007. Effects of extruded linseed dietary supplementation on milk yield, milk quality and lipid metabolism of dairy cows. Ital. J. Anim. Sci. 6:333-335. https://doi.org/10.4081/ijas.2007.1s.333.

Pottier, J., M. Focant, C. Debier, G. De Buysser, C. Goffe, E. Mignolet, E. Froidmont, and Y. Larondelle. 2006. Effect of dietary vitamin $\mathrm{E}$ on rumen biohydrogenation pathways and milk fat depression in dairy cows fed high-fat diets. J. Dairy Sci. 89:685-692. https://doi.org/10.3168/jds.S0022-0302(06)72131-2.

R Core Team. 2016. R: A Language and Environment for Statistical Computing. R Foundation for Statistical Computing, Vienna, Austria.

Rabiee, A. R., K. Breinhild, W. Scott, H. M. Golder, E. Block, and I. J. Lean. 2012. Effect of fat additions to diets of dairy cattle on milk production and components: A meta-analysis and metaregression. J. Dairy Sci. 95:3225-3247. https://doi.org/10.3168/ jds.2011-4895.

Rajaram, S. 2014. Health benefits of plant-derived linolenic acid Am. J. Clin. Nutr. 100:443S-448S. https://doi.org/10.3945/ ajcn.113.071514.

Reddy, P. V., J. L. Morrill, and T. G. Nagaraja. 1994. Release of free fatty acids from raw of processed soybeans and subsequent effects on fiber digestibilities. J. Dairy Sci. 77:3410-3416. http://dx.doi. org/https://doi.org/10.3168/jds.S0022-0302(94)77283-0.

Rodney, R. M., P. Celi, W. Scott, K. Breinhild, and I. J. Lean. 2015. Effects of dietary fat on fertility of dairy cattle: A meta-analysis and meta-regression. J. Dairy Sci. 98:5601-5620. https://doi org/10.3168/jds.2015-9528.

Roy, A., J.-M. Chardigny, D. Bauchart, A. Ferlay, S. Lorenz, D. Durand, D. Gruffat, Y. Faulconnier, J.-L. Sébédio, and Y. Chilliard. 2007. Butters rich either in trans-10-C18:1 or in trans-11-C18:1 plus cis-9, trans-11 CLA differentially affect plasma lipids and aortic fatty streak in experimental atherosclerosis in rabbits. Animal 1:467. https://doi.org/10.1017/S175173110770530X.

Roy, A., A. Ferlay, K. J. Shingfield, and Y. Chilliard. 2006. Examination of the persistency of milk fatty acid composition responses to plant oils in cows given different basal diets, with particular emphasis on trans-C18:1 fatty acids and isomers of conjugated linoleic acid. Anim. Sci. 82:479-492. https://doi.org/10.1079/ASC200658.

Sauvant, D., P. Schmidely, J. J. Daudin, and N. R. St-Pierre. 2008. Meta-analyses of experimental data in animal nutrition. Animal 2:1203-1214. https://doi.org/10.1017/S1751731108002280.

Shingfield, K. J., L. Bernard, C. Leroux, and Y. Chilliard. 2010. Role of trans fatty acids in the nutritional regulation of mam- mary lipogenesis in ruminants. Animal 4:1140-1166. https://doi org/10.1017/S1751731110000510.

Simopoulos, A. P. 2008. The importance of the omega-6/omega-3 fatty acid ratio in cardiovascular disease and other chronic diseases. Exp. Biol. Med. (Maywood) 233:674-688. https://doi. org/10.3181/0711-MR-311.

Smith, W. a., B. Harris, H. H. Van Horn, and C. J. Wilcox. 1993 Effects of forage type on production of dairy cows supplemented with whole cottonseed, tallow, and yeast. J. Dairy Sci. 76:205-215. https://doi.org/10.3168/jds.S0022-0302(93)77339-7.

Średnicka-Tober, D., M. Barański, C. J. Seal, R. Sanderson, C. Benbrook, H. Steinshamn, J. Gromadzka-Ostrowska, E. Rembiałkowska, K. Skwarło-Sońta, M. Eyre, G. Cozzi, M. K. Larsen, T. Jordon, U. Niggli, T. Sakowski, P. C. Calder, G. C. Burdge, S. Sotiraki, A Stefanakis, S. Stergiadis, H. Yolcu, E. Chatzidimitriou, G. Butler, G. Stewart, and C. Leifert. 2016. Higher PUFA and n-3 PUFA, conjugated linoleic acid, $\alpha$-tocopherol and iron, but lower iodine and selenium concentrations in organic milk: A systematic literature review and meta- and redundancy analyses. Br. J. Nutr. 115:1043-1060. https://doi.org/10.1017/S0007114516000349.

Sterk, A., R. Hovenier, B. Vlaeminck, A. M. van Vuuren, W. H. Hendriks, and J. Dijkstra. 2010. Effects of chemically or technologically treated linseed products and docosahexaenoic acid addition to linseed oil on biohydrogenation of C18:3n-3 in vitro. J. Dairy Sci. 93:5286-5299. https://doi.org/10.3168/jds.2010-3144.

Sterk, A., B. E. O. Johansson, H. Z. H. Taweel, M. Murphy, A. M. van Vuuren, W. H. Hendriks, and J. Dijkstra. 2011. Effects of forage type, forage to concentrate ratio, and crushed linseed supplementation on milk fatty acid profile in lactating dairy cows. J. Dairy Sci. 94:6078-6091. https://doi.org/10.3168/jds.2011-4617.

Sterk, A., B. Vlaeminck, A. M. van Vuuren, W. H. Hendriks, and J. Dijkstra. 2012. Effects of feeding different linseed sources on omasal fatty acid flows and fatty acid profiles of plasma and milk fat in lactating dairy cows. J. Dairy Sci. 95:3149-3165. https://doi org $/ 10.3168 /$ jds.2011-4474.

Troegeler-Meynadier, A., S. Puaut, Y. Farizon, and F. Enjalbert. 2014. Effects of the heating process of soybean oil and seeds on fatty acid biohydrogenation in vitro. J. Dairy Sci. 97:5657-5667. https://doi.org/10.3168/jds.2013-7783.

Weimer, P. J., D. M. Stevenson, and D. R. Mertens. 2010. Shifts in bacterial community composition in the rumen of lactating dairy cows under milk fat-depressing conditions. J. Dairy Sci. 93:265278. https://doi.org/10.3168/jds.2009-2206.

Zened, A., F. Enjalbert, M. C. Nicot, and A. Troegeler-Meynadier. 2013. Starch plus sunflower oil addition to the diet of dry dairy cows results in a trans-11 to trans-10 shift of biohydrogenation. J. Dairy Sci. 96:451-459. https://doi.org/10.3168/jds.2012-5690.

Zened, A., A. Troegeler-Meynadier, M. C. Nicot, S. Combes, L. Cauquil, Y. Farizon, and F. Enjalbert. 2011. Starch and oil in the donor cow diet and starch in substrate differently affect the in vitro ruminal biohydrogenation of linoleic and linolenic acids. J. Dairy Sci. 94:5634-5645. https://doi.org/10.3168/jds.2011-4491. 